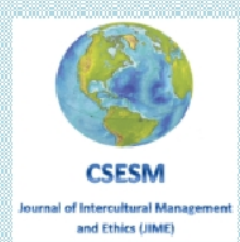

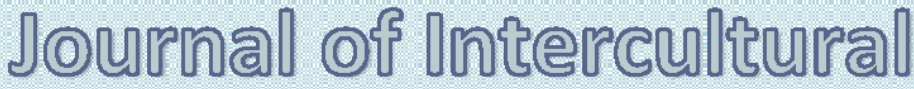

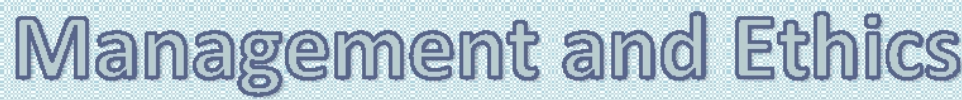

\author{
I0ME
}

ISSN 2601 - 5749, ISSN-L 2601 - 5749

Center for Socio-Economic Studies and Multiculturalism

lasi, Romania

WWW csesmioirg 


\section{TABLE OF CONTENT}

Editorial

Iulian Warter

Where Did Culture Come From? Evolutionary Foundations of Cultural Diversity

Paulo Finuras

Crash: Boeing and the Power of Culture

Thomas D. Zweifel, Vip Vyas

Political Culture, Social Polarization and Electoral Behavior. The Last Decade in Romanian

Political System

Silviu-Petru Grecu

The Principles of Transparency and Judging Others Favorably: The Talmudic View

Hershey H. Friedman, Robert B. Fireworker

Some Issues Regarding the Ethics of the Management at Romanian State-Owned

Companies .55

Baluta Aurelian Virgil, Rada Alexandru Cristian

How Does Logistics Command of the Military Navy Support Local Development and

Cultural Integration?

Rosa Caiazza

Illusion and Disillusion. Case Studies about the Constitution of a New Political Party in

Romania

Alexandru Muraru

How Could We Overcome the Feeling Of Insecurity? Explorations in the Spectrum of Polyscopic Consciousness

Anton Carpinschi

The Employees' Perceptions, Practices and Experiences Regarding the Strategic Process

Carried Out In the Public Hospitals

Ana Niculita 


\title{
THE PRINCIPLES OF TRANSPARENCY AND JUDGING OTHERS FAVORABLY: THE TALMUDIC VIEW
}

\author{
Hershey H. Friedman, Ph.D. \\ Professor of Business \\ Department of Business Management, Koppelman School of Business \\ Brooklyn College of the City University of New York, USA \\ E-mail: x.friedman@att.net \\ Robert B. Fireworker, Ph.D. \\ Professor of Computer Information Systems and Decision Sciences \\ Peter J. Tobin College of Business, St. John's University, USA \\ E-mail:bobprof@gmail.com
}

\begin{abstract}
Many scholars believe that conflicts of interest are an ethical issue and a critical impediment to effective management. An organization interested in functioning honestly and efficiently should first do everything possible to reduce or eliminate this problem. The current opioid crisis responsible for the deaths of hundreds of thousands of Americans and the Great Recession of 2008 have been attributed to conflicts of interest in the pharmaceutical industry and the financial sector, respectively. In order to understand these modern problems, this paper examines two relevant and seemingly contradictory Talmudic principles: First, that a person is required to behave in a transparent manner and not act in a way that will cause others to suspect that $\mathrm{s} / \mathrm{he}$ is doing something immoral or unethical. Second, that one should judge others favorably and give them the benefit of the doubt. The problem of persistent rumors about misbehavior is also studied.
\end{abstract}

Keywords: Business ethics, Talmud, trust in capitalism, conflicts of interest, transparency, judging others favorably, persistent rumors, Wells Fargo, opioid crisis, B corporation.

\section{Introduction}

Trust in capitalism and business is quite low; this is a significant problem because capitalism needs trust to function correctly, and there is a consensus that corruption harms economic growth (Chêne, 2014).

Recent surveys of Americans demonstrate that the majority do not have much confidence in the corporate world, which is especially true for young people between 18 and 29 (Admati, 2019). Peter Georgescu has written, "For the past four decades, capitalism has slowly been committing suicide" (cited in Oliveira, 2018). There is a severe crisis of trust that seems to be plaguing leaders of all kinds of institutions, including business, education, religion, government, and health care (Annan, 2016; Monahan, 2012; Pearse, 2018; Shahid, 2014; Veldsman, 2016; World Economic Forum, 2014). Because there is evidence that organizational conduct flows from the top down, a firm concerned about ethically running a business must start at the top (Mayer et al., 2009). Many CEOs have been more concerned about current profits than manufacturing safe, quality products which, in effect, means the long-term strength of an organization is being sacrificed for short-term goals (Friedman \& Kass, 2018). The job of the CEO is to create an ethical culture in the workplace (Ardichvili \& Jondle, 2009). 
Bazerman and Tenbrunsel (2011) assert that a considerable amount of money is spent to ensure compliance with codes of ethics - about one million for every billion dollars in sales. Despite this, questionable behavior remains relatively common, and there continue to be numerous ethical lapses in business and government. For example, the national opioid settlement will be billions of dollars. The companies involved include Johnson \& Johnson, AmerisourceBergen, Cardinal Health, and McKesson. These drug companies have been accused of aggressively marketing opioids (Mann, 2021). Purdue Pharma has pleaded guilty to fraud and kickback conspiracies in marketing its opioid, Oxycontin, and will pay billions of dollars as part of its settlement (Department of Justice, 2020).

The opioid crisis that resulted in the death of hundreds of thousands of Americans (Spithoff et al., 2020) can be directly attributed to conflicts of interest in the pharmaceutical industry. The Great Recession of 2008 also resulted from numerous conflicts of interest throughout the financial sector (Greycourt, 2008). Bell, Friedman, and Friedman posit:

Conflicts of interest are more than an ethical issue: They are quite possibly the major obstacle confronting effective management today. The first task of a firm that is interested in running efficiently is eliminating or reducing the presence of conflicts of interest (Bell, Friedman, \& Friedman, 2005, p. 7).

Hunter Biden, the president's son who has no formal training as an artist, is being criticized for selling his artwork, some of which are expected to sell for as much as $\$ 500,000$. The buyers of the paintings are supposed to remain anonymous - the gallery owner will not reveal the buyers' identities. The fear is that people would buy the artwork to gain influence with President Biden. However, word has leaked out that Hunter will be meeting with prospective purchasers at the art shows displaying his paintings; there are questions as to whether this violates the agreement to keep everything anonymous (Moore, 2021). It is not clear whether this is ethical or not, but it certainly looks bad. Also, is it possible to stop purchasers of the art from using social media to publicize that they own paintings by Hunter? This is reminiscent of how Trump's International Hotel in Washington D.C. became the inplace for foreign diplomats, international businesspeople, power brokers, lobbyists, and those hoping to gain influence with Donald Trump (Altman, 2017).

A firm that wants to be ethical must embrace transparency. Transparency is crucial if an organization seeks to maintain an engaged and happy labor force.

$[\mathrm{M}]$ anagement transparency coming in at an extremely high correlation coefficient of .937 with employee happiness. The cost of improving transparency is almost zero, but requires an ongoing dialogue between management and staff. We see an increasing number of companies using transparency to attract and retain top talent. (Lipman, 2013, para. $3)$.

Almost 2,000 years ago, the Talmud was concerned about the effect of conflicts of interest on ethical behavior (Fogel \& Friedman, 2008). One might maintain that ethical conduct is virtually impossible in the presence of conflicts of interest. This paper will examine two essential teachings discussed in the Talmud that relate to the above situations.

(1) A person is required to behave in an aboveboard manner and not act in a way that will cause others to suspect that s/he is doing something immoral or unethical; and

(2) A person should judge others favorably. Even in situations where it appears that someone may have done something iniquitous or dishonest, we should give the person the benefit of the doubt and assume that they acted appropriately. These two teachings are related, and this paper will examine them.

This paper uses the William Davidson Talmud available for public use at the Sefaria.org website (https://www.sefaria.org/texts/Talmud). The English translation is based 
on Rabbi Adin Steinsaltz's Even-Israel translation, including explanations. Another translation available for free on the internet is the Soncino Talmud. It may be found at: https:/halakhah.com/ and the Ancient World Online websites (http://ancientworldonline.blogspot.com/2012/01/online-soncino-babylonian-talmud.html). A third translation of the Talmud is by ArtScroll, published by Mesorah Publications, Ltd. and may be purchased at the ArtScroll website (http://www.artscroll.com/).

\section{The Requirement to Behave in a Transparent Manner}

The Talmud requires a person to behave in an aboveboard manner to ensure that $\mathrm{s} / \mathrm{he}$ is above suspicion. This is derived from a verse in the Torah: "You shall be innocent before God and Israel" (Numbers 32:22). This verse is interpreted to mean that people should not behave in a manner that might arouse the suspicions of others. These questions can involve dishonesty in business or sexual misconduct. Another verse hints at this law. Demonstrating the importance of keeping open records, Scripture enumerates the amount of gold, silver, and copper used in the Tabernacle's construction (Exodus 38: 21- 31). Moreover, the Bible tells us who was ultimately responsible for guaranteeing that accurate records were kept: "These are the accounts of the Tabernacle, the Tabernacle of the Testimony, as they were calculated according to the commandment of Moses..." (Exodus 38:21).

Moses wanted to show that he was above suspicion and make it evident to the Israelites that no precious metals were diverted for anyone's personal use. Thus, he commanded outsiders to audit the books. The Midrash comments: "... though Moses was the sole treasurer, yet he called others to audit the accounts with him" (Midrash Exodus Rabbah 51: 1).

The Talmud states that the overseers of the soup kitchen were not allowed to purchase surplus food when there were no poor people to whom to distribute it. Surpluses were permitted only to be sold to others, not to arouse suspicion that the charity overseers profited from public funds (Babylonian Talmud, Pesachim 13a).

Collectors of charity who have no poor people to whom they can distribute the money, change the money with other people and do not change it themselves, i.e., with their own coins. Likewise, collectors of food for the charity plate, who would collect food in large vessels for the poor to eat, who do not have poor people to whom to distribute the food, sell the food to others and do not sell it to themselves, as it is stated: "And you shall be guiltless before God and before Israel" (Numbers 32:22). It is not sufficient that a person is without $\sin$ in the eyes of God. He must also appear upright in the eyes of other people so that they will not suspect him of wrongdoing (Babylonian Talmud, Pesachim 13a; Sefaria.org translation).

The Talmud relates how the family of Garmu, which made the showbread for the Temple, was meticulous to be above suspicion. Thus, their children were never seen with fine bread.

And for this matter they are mentioned favorably: Never was refined bread of fine flour found in the hands of their descendants, so that people would not say that they are sustained from that technique of preparing the shewbread. They ate only bread made of coarse flour mixed with bran, to fulfill that which is stated: "And you shall be guiltless before the Lord and before Israel" (Numbers 32:22). Not only must one's behavior be beyond reproach, but he should also make 
certain to be beyond suspicion (Babylonian Talmud, Yuma 38a; Sefaria.org translation).

Brides from the family of Abtimas never wore perfume since this family made the incense for the Temple (Babylonian Talmud, Yuma 38a).

And for this matter they are mentioned favorably: Never did a perfumed bride emerge from their homes. And when they marry a woman from a different place, they stipulate with her that she will not perfume herself, so that cynics would not say that it is with the work of the incense that they perfume themselves, to fulfill that which is stated: "And you shall be guiltless before the Lord and before Israel" (Numbers 32:22) (Babylonian Talmud, Yuma 38a; Sefaria.org translation).

Those who entered the Temple chamber to collect the money (for the sacrifices) did not wear clothing with a place to hide money, i.e., they only wore clothing with no pockets or other receptacles so that people would not suspect them of stealing money. The reason: "Because a person must be above suspicion before people as well as before God" (Mishna Shekalim 3:2).

The one who made the appropriation did not enter the chamber wearing a bordered cloak, or shoes, or sandals, or tefillin, or an amulet, lest he become poor and [people] say that he became poor because of a sin committed in the chamber, or lest he become rich and [people] say that he became rich from the appropriation in the chamber. For one must be free of blame before others as he must be free of blame before God, as it is said: "And you shall be guiltless before the Lord and before Israel" (Numbers 32:22), and it says: "And you will find favor and good understanding in the eyes of God and man" (Proverbs 3:4) (Mishna Shekalim 3:2; Sefaria.org translation)

There is no question that people are required to behave in a manner that does not arouse others the suspicions of others. This is why one is not permitted to go into an abandoned ruin. Someone seeing a man entering such a place will automatically suspect that he is meeting someone there to commit a sexual transgression.

Rabbi Yossi said: I was once walking along the road when I entered the ruins of an old, abandoned building among the ruins of Jerusalem in order to pray. I noticed that Elijah, of blessed memory, came and guarded the entrance for me and waited at the entrance until I finished my prayer. When I finished praying and exited the ruin, Elijah said to me, deferentially as one would address a Rabbi: Greetings to you, my Rabbi. I answered him: Greetings to you, my Rabbi, my teacher. And Elijah said to me: My son, why did you enter this ruin? I said to him: In order to pray. And Elijah said to me: You should have prayed on the road. And I said to him: I was unable to pray along the road, because I was afraid that I might be interrupted by travelers and would be unable to focus. Elijah said to me: You should have recited the abbreviated prayer instituted for just such circumstances.

Rabbi Yossi concluded: At that time, from that brief exchange, I learned from him, three things: I learned that one may not enter a ruin; and I learned that one need not enter a building to pray, but he may pray along the road; and I learned that one who prays along the road 
recites an abbreviated prayer so that he may maintain his focus.

(Babylonian Talmud, Berachos 3a; Sefaria.org translation)

This teaching has many obvious ramifications when it comes to individuals and organizations. People must behave in an aboveboard manner and disclose any conflicts of interest. Corporations and organizations should also act transparently and thus not cause others to be suspicious of what they are doing. This includes using truly independent auditors and avoiding situations that give rise to conflicts of interest. Charities should be "audited" by Charity Navigator so that the public is aware of their "level of commitment to being accountable and transparent" (https://www.charitynavigator.org/). Financial statements issued by all organizations should clearly state all assumptions made and be as accurate, honest, and understandable as possible. The purpose of financial statements and news releases should be to inform and enlighten, not to confuse investors or hide information in footnotes.

\section{Giving Someone the Benefit of the Doubt}

The other side of the coin is that one should not wrongfully suspect another of misdeeds. This is known as choshed bichsherim (also spelled choshed b'ksherim), which means having doubts about the innocent. The other party should be given the benefit of the doubt if it is not clear whether s/he committed a misdeed. Rabbi Yehoshua ben Perachiah stated: "Make a teacher for yourself, acquire a friend, and judge all people favorably" (Avos 1: 6). Similarly, Hillel averred:

"Do not judge your fellow human being until you have been in his place (Avos 2:4).

The Talmud states: "Whoever judges his fellow-man favorably [when someone's actions seem suspicious and can be interpreted either for good or for bad], will himself be judged favorably [by Heaven]" (Babylonian Talmud, Shabbos 127b). The Talmud notes:

There are six things that a person eats the fruits [the interest] in this world yet the principal remains for him in the next world [the afterlife].

They are: hospitality, visiting the sick, devotion and meditation in prayer, early attendance at the house of study, raising one's sons to study Torah, and judging one's fellow-man favorably [when someone's actions seem suspicious and can be interpreted either for good or for bad] (Rabbi Yehuda b. Shila in the name of Rabbi Assi in the name of Rabbi Yochanan, Shabbos 127a).

Thus, one is obligated to judge another person favorably. The Talmud (Babylonian Talmud, Yuma 19b) indicates the punishment for not evaluating another person favorably: "One who suspects an innocent person of a misdeed is punished by being stricken in his body." The Talmud derives this from the Torah.

Rabbi Shimon ben Lakish (known as Resh or Reish Lakish throughout the Talmud) derived the principle that one is punished for not giving another party the benefit of the doubt from the following.

On the topic of Miriam's leprosy, the Gemara cites that which Reish Lakish said: One who suspects the innocent of indiscretion is afflicted in his body, as it is written: "And Moses answered and said: But they will not believe me and will not hearken to my voice, for they will say, God did not appear to you" (Exodus 4:1), and it is revealed before the Holy One, Blessed be He, that the Jewish people would believe. The Holy One, Blessed be He, said to Moses: They are believers, the children of believers; and ultimately, you will not believe.

They are believers, as it is written: "And the people believed once they heard that God had remembered the children of Israel, and that He saw their affliction, and they bowed and they prostrated" (Numbers 
4:31). The children of believers, as it says with regard to Abraham our Patriarch: "And he believed in God, and He counted it for him as righteousness" (Genesis 15:6). Ultimately, you will not believe, as it is stated: "And God said to Moses and to Aaron: Because you did not believe in Me to sanctify Me in the eyes of the children of Israel" (Numbers 20:12). From where do we know that Moses was afflicted in his body? As it is written (Exodus 4:6): "And God said to him further: Bring your hand to your bosom, and he brought his hand to his bosom and he took it out and behold, his hand was leprous like snow" (Babylonian Talmud, Shabbos 97a; Sefaria.org translation).

The Talmud also discusses where Miriam and Aaron spoke against Moses for marrying a Cushite woman (Numbers 12: 1-16). Miriam was punished with leprosy for this slander. It is unclear whether their transgression involved slandering Moses and/or being suspicious of his motives. The identity of the Cushite woman is also not apparent; many commentaries say she was Tzipporah, daughter of Jethro. According to some opinions, the slander occurred after Miriam discovered that Moses refrained from having relations with his wife. Miriam thought that this was arrogant of Moses since God also spoke to Aaron and her, and they did not refrain from having marital relations with their spouses. The sin of Miriam and Aaron appears to be a combination of slander and suspicion of Moses' motives.

Rabbi Akiva felt that this punishment was also meted out to Aaron.

On a similar note, Rabbi Akiva revealed an additional matter not explicitly articulated in the Torah. You say that when Aaron and Miriam spoke against Moses, both Aaron and Miriam were struck with leprosy, as it is written: "And God became angry at them and $\mathrm{He}$ left, and the cloud departed from above the tent, and behold, Miriam was leprous like snow. And Aaron turned toward Miriam, and behold, she was leprous" (Numbers 12:9-10). The verse's statement that God became angry at both of them teaches that Aaron, too, became leprous; this is the statement of Rabbi Akiva. Rabbi Yehuda ben Beteira said to him: Akiva, in either case you will be judged in the future for this teaching. If the truth is in accordance with your statement, the Torah concealed Aaron's punishment and you reveal it. And if the truth is not in accordance with your statement, you are unjustly slandering that righteous man (Babylonian Talmud, Shabbos 97a; Sefaria.org translation).

Moses was a very humble person and begged God to forgive Miriam in one of the tersest (five words in Hebrew) yet eloquent prayers (Numbers 12: 13): "Please God, heal her now!"

Not only is one required to give another person the benefit of the doubt, but the Talmud also states that if someone wrongly suspects an innocent person, s/he is obligated to bless him. The person must also inform the person who doubted him that he is innocent. This is derived from the story of Eli the priest and Hannah. Eli suspected Hannah of drunkenness because of how she was praying -- her lips moved, but her voice was not heard (I Samuel $1: 12-13)$.

With regard to Hannah's explanation that "I have drunk neither wine nor liquor," Rabbi Elazar said: From here the halakha [Jewish law] is derived that one who is suspected of something of which he is not guilty cannot suffice merely with the personal knowledge of his innocence, but must inform the one who suspects him that he is innocent and clear himself of suspicion... 
"And Eli answered and said: May you go in peace" (I Samuel 1:17). Rabbi Elazar said: From here the halakha is derived that one who suspects another of something that he has not done, he must appease him. Moreover, the one who suspected him must bless him, as Eli continued and offered Hannah a blessing, as it is stated (I Samuel 1:17): "And may the God of Israel grant your request that you have asked of Him" (Babylonian Talmud, Berachos 31b).

There is a special reward for an innocent person suspected of a misdeed. The Talmud believes the humiliation of being mistakenly considered a wrongdoer is so great that Heaven will eventually reward the victim as compensation.

And Rabbi Yossi said: May my portion be with one whom others suspect of sin and there is no basis for suspecting him. Rav Pappa said: They suspected me, and there was no basis for suspecting me (Babylonian Talmud, Shabbos 118b).

The following three stories are used to illustrate the importance of judging another person favorably.

The Sages taught in a Baraita: One who judges another favorably is himself judged favorably. And there was an incident involving a certain person who descended from the Upper Galilee and was hired to work for a certain homeowner in the South for three years. On the eve of the Day of Atonement, he said to the homeowner: Give me my wages, and I will go and feed my wife and children. The homeowner said to him: I have no money. He said to him: In that case, give me my wages in the form of produce. He said to him: I have none. The worker said to him: Give me my wages in the form of land. The homeowner said to him: I have none. The worker said to him: Give me my wages in the form of animals. He said to him: I have none. The worker said to him: Give me cushions and blankets. He said to him: I have none. The workerslung his tools over his shoulder behind him and went to his home in anguish.

After the festival of Sukkot, the homeowner took the worker's wages in his hand, along with a burden that required three donkeys, one laden with food, one laden with drink, and one laden with types of sweets, and went to the worker's home. After they ate and drank, the homeowner gave him his wages. The homeowner said to him: When you said to me: Give me my wages, and I said: I have no money, of what did you suspect me? Why did you not suspect me of trying to avoid paying you? The worker answered, I said: Perhaps the opportunity to purchase merchandise inexpensively presented itself, and you purchased it with the money that you owed me, and therefore you had no money available. The homeowner asked: And when you said to me: Give me animals, and I said: I have no animals, of what did you suspect me? The worker answered: I said: Perhaps the animals are hired to others. The homeowner asked: When you said to me: Give me land, and I said: I have no land, of what did you suspect me? The worker answered: I said: Perhaps the land is leased to others, and you cannot take the land from the lessees. The homeowner asked: And when you said to me: Give me produce, and I said: I have no produce, of what did you suspect me? The worker answered: I said: Perhaps they are not tithed, and that was why you could not give them to me. 
The homeowner asked: And when I said: I have no cushions or blankets, of what did you suspect me? The worker answered: I said: Perhaps he consecrated all his property to Heaven and therefore has nothing available at present.

The homeowner said to him: I swear by the Temple service that it was so. I had no money available at the time because I vowed and consecrated all my property on account of Hyrcanus, my son, who did not engage in Torah study. The homeowner sought to avoid leaving an inheritance for his son. And when I came to my fellow residents in the South, the Sages of that generation, they dissolved all my vows. At that point, the homeowner had immediately gone to pay his worker. Now the homeowner said: And you, just as you judged favorably, so may God judge you favorably (Babylonian Talmud, Shabbos 127b; translation by Sefaria.org).

On a similar note, the Gemara relates that the Sages taught in a Baraita: There was an incident involving a certain pious man who redeemed a young Jewish woman from captivity. When they arrived at the inn he had her lie beneath his feet. The next day, he descended, and immersed in a ritual bath to purify himself before Torah study and prayer, and taught his students. This conduct could arouse suspicion that the pious man kept the maiden for himself, as immersion in the morning is customary for men who have experienced a seminal emission by engaging in sexual relations. And the pious man said to his students: When I had her lie beneath my feet, of what did you suspect me? They said to him: We said: Perhaps there is a student among us whose conduct is not established before the Rabbi, and he wanted to make certain that this student would not inappropriately accost the young woman. Therefore, the Rabbi kept the woman close by. He said to them: When I descended and immersed, of what did you suspect me? They answered: Perhaps due to the exertion of travel, a seminal emission befell the Rabbi. He said to them: I swear by the Temple service that it was so. And you, just as you judged me favorably, so may God judge you favorably (Babylonian Talmud, Shabbos 127b; translation by Sefaria.org).

The Sages taught a similar Baraita: Once there was a certain matter needed by Torah scholars. They wanted to discuss an issue with a certain matron whose company was kept by all the prominent people of Rome. The Torah scholars wanted to address the government on behalf of the Jewish people, and they sought the matron's advice. They said: Who will go? Rabbi Yehoshua said to them: I shall go. Rabbi Yehoshua and his students went to her. When he arrived with his students at the entrance of her house, he removed his phylacteries at a distance of four cubits from the door, and entered, and locked the door before them. After he emerged, he descended and immersed in a ritual bath, and taught his students. Here too, this was conduct that could arouse suspicion that something improper transpired. And he said to his students: When I removed the phylacteries, of what did you suspect me? They said to him, we said: The Rabbi must hold that sacred items may not enter a place of impurity. Therefore, it would have been inappropriate to enter the 
house with phylacteries. He asked: When I locked the door, of what did you suspect me? They said to him: We said: Perhaps there is a discreet royal matter that must be discussed between him and her and should not be revealed. Rabbi Yehoshua asked: When I descended and immersed, of what did you suspect me? They said to him, we said: Perhaps a bit of spittle sprayed from her mouth onto the Rabbi's clothes. The Sages decreed that the legal status of a gentile is like that of a $z a v$; their bodily fluids transmit ritual impurity. Rabbi Yehoshua said to them: I swear by the Temple service that it was so. And you, just as you judged favorably, so may God judge you favorably (Babylonian Talmud, Shabbos 127b; translation by Sefaria.org).

The principle of not suspecting the innocent and judging others favorably appears to contradict a well-known Talmudic saying that "Let all persons always be in your eyes as robbers, but honor each with the respect due to Rabban Gamliel" (Kallah Rabbati, Chapter 9). Indeed, the following story is related to support this view:

It is related of Rabbi Yehoshua that he extended hospitality to all. A man arrived to whom he gave food and drink, took up to the attic and then removed the ladder from under him. What did the man do? $\mathrm{He}$ arose in the middle of the night, spread out his cloak, took the vessels belonging to the room which he wrapped up in his cloak and was about to descend when he fell and broke his collarbone. In the morning, Rabbi Yehoshua came and, finding him on the ground, said to him, "You worthless person, do men act like you?" He replied: "I did not know that you had removed the ladder from under me." Rabbi Yehoshua said to him: "Were you not aware that we were on our guard against you since yesterday?" (Kallah Rabbati, Chapter 9; translation by Soncino).

This contradiction is noted by the Talmud (Kallah Rabbati, Chapter 9). The answer given is that if the person is known to you, s/he should be judged favorably. A person not known to you should justifiably be suspected of being a potential criminal, albeit treated like royalty. This question is discussed by Taubes (2010), who cites several sources that state "innocent ones" (ksherim) implies that people who are known to be wicked should not be judged favorably. One may assume that evil people have acted immorally.

Taubes (2010) cites Rabbi Yonah Gerondi (c. 1200- 1263), who says in his classic work, Sha'arei Teshuva (Sha'ar 3:221-222) that the Torah requires one to judge others favorably. He derives this from the verse (Leviticus 19:15): "with righteousness you shall judge your fellow." Rabbi Yonah, however, highlights the fact that this does not apply to a wicked person. An average person, one that tries to avoid sinning but occasionally succumbs, that person should be judged favorably. This is the kind of person the rabbis meant when saying: "Whoever judges his fellow-man favorably, will himself be judged favorably by Heaven." One might add that "judging favorably" probably does not include taking a chance with the lives of one's family. Rabbi Yehoshua did the intelligent thing.

Interestingly, Rabbi Yonah Gerondi was involved in the campaign against Maimonides' philosophical works, which eventually ended with the burning of Maimonides' books by the Inquisition (probably around 1232). In 1240, the Talmud was burnt by the Inquisition in the same spot where the books of Maimonides had been burnt. Rabbi Yonah took this as a sign of divine punishment and repented saying: "I undertake to prostrate myself at Maimonides' grave and to confess that I spoke and sinned against his books" (Jewish Virtual Library, 2017). Some believe that his work, Sha'arei Teshuvah, was written as part of 
his penance for his role in suspecting Maimonides of heresy and getting his books burned. There is, however, no concrete evidence of this. See Judaism.stackexchange for more about this subject. (https://judaism.stackexchange.com/questions/66759/did-rabbeinu-yonah-writeshaarei-teshuva-in-response-to-the-burning-of-the-gemar)

\section{Persistent Rumors of Reprehensible Behaviors}

There may be an obligation to judge another person favorably. However, if there is a persistent rumor that a person is engaged in reprehensible behaviors, do we ignore it or take it seriously and investigate? The Talmud addresses this question.

Rav said in the name of Rabbi Reuven ben Itzterobili, and some say that it was taught in a Baraita that Rabbi Reuven ben Itzterobili said: A man is suspected of having done something wrong only if he has indeed done so. And if he did not do it wholly, then probably he did it partly. And if he did not do it even partly, then probably he thought in his heart to do it. And if he did not even think to himself to do it, then certainly he saw others doing it and was happy. Suspicions do not arbitrarily arise about a person; therefore is certainly some basis for them.

Rabbi Ya'akov raised an objection: Does the verse not say: "And the children of Israel fabricated matters that were not right against the Lord their God" (II Kings 17:9), which indicates that it is possible to make up stories about someone else even though they are entirely baseless. The Gemara answers: There they did it in order to anger God, but they did not actually think that what they were saying was true.

Come and hear a challenge from a different source: The verse states: "And they were jealous of Moses in the camp, of Aaron the Lord's holy one" (Psalms 106:16). Rav Shmuel bar Yitzhak said: This verse teaches that every man warned his wife against seclusion with Moses because he was jealous. This implies that every man thought that his wife had secluded herself with Moses and sinned, although this was certainly not the case. This demonstrates that it is possible to suspect an absolutely innocent person. The Gemara answers: There they did it out of hatred for Moses. They did not actually suspect him of wrongdoing. Instead, their goal was to degrade him by leveling these false accusations against him.

The Gemara raises another challenge, based on yet another source: Come and hear that which Rabbi Yossi said: May my portion in the future world be with one who is suspected of a certain wrongdoing but is innocent, as the pain that such a person experiences atones for his sins. This statement also appears to imply that it is possible to suspect an absolutely innocent person. And Rav Pappa said: They suspected me of a certain wrongdoing but I was not guilty. The Gemara answers: It is not difficult. This is referring to a rumor that stops, and therefore it is possible that it is groundless, whereas that is referring to a rumor that does not stop, and in that case there must be a factual basis for the suspicion. The Gemara asks: To be considered a rumor that does not stop, for how long must it persist? Abaye said: My nurse told me: Local gossip lasts for a day and a half, and then it is deemed to be a rumor that does not stop. 
The Gemara comments: This applies only if the rumor did not stop in between, during the day and a half, but if it stopped in between then we have no problem with it, and it is not a persistent rumor. And if the rumor stopped in between, we said that it is considered baseless only if it stopped of its own accord and not out of fear, i.e., because the suspect is violent and therefore people are afraid to speak badly about him. But if the rumor stopped out of fear, then this dispensation does not apply, and it is still assumed that there must be some basis to the rumor. And we said that a rumor that stopped is assumed to be baseless only if it did not arise again. But if it arose again, then this does not apply. And we said that a rumor that does not stop must be taken seriously only if the slandered person has no enemies. But if he has known enemies, then it can be assumed that it was the enemies who disseminated the rumor (Babylonian Talmud, Moed Katan 18b; Sefaria.org translation).

A summary of this is provided in the ArtScroll translation of the Talmud (note 63)

A rumor directed at someone who has enemies carries no weight even if it does not stop at all (Ritva, citing Rashi)... A rumor is assumed to have substance if its subject has no enemies and it endures for at least one and a half days without stopping. If it stopped prematurely and then restarted, it is baseless, unless it stopped as a result of fear or it restarted with the same intensity as before (Moed Katan 18b, ArtScroll translation, note 63).

The Talmudic guidelines indicate the importance of checking out persistent rumors. There have been rumors at organizations regarding corruption or sexual harassment by a key official. Numerous complaints about sexual harassment and/or other inappropriate behaviors have been leveled at such celebrities as Roger Ailes, Bill Cosby, and Bill O'Reilly. Fox News spent over $\$ 13$ million over the last 13 years settling claims about sexual harassment by O'Reilly (Cauterucci, 2017). Many organizations pay considerable settlements to cover up the allegations rather than investigate. Whistleblowers are often fired for playing a role in keeping the rumor alive. In January 2010, the Office of the Comptroller of the Currency (OCC), a federal banking regulator, was aware of "700 cases of whistleblower complaints" about Wells Fargo's dishonest sales tactics and did not do anything (Egan, 2017). Wells Fargo has admitted to creating as many as 2 million fake, unauthorized bank accounts.

\section{Conclusion}

The Edelman 2020 Trust Barometer found that $56 \%$ of respondents to a worldwide survey in 28 countries believe that "capitalism as it exists today does more harm than good" (Carlisle, 2020). The study found that people do not trust institutions, and the solution is to rebuild trust with ethical behavior. Many scholars believe that capitalism has to evolve into something new and more focused on people and society. There is a growing movement to focus more on people and society than profits to ensure that capitalism survives. This is why many companies have been talking about redefining the purpose of a corporation. The idea that firms should provide a benefit to society is gaining traction worldwide.

B Corporations, or benefit corporations, a label created by B Lab in 2006, legally agree to balance profit and purpose and satisfy the highest transparency, accountability, and social and environmental performance standards. They commit to producing a benefit for society and want to use business as a force for improving the world, not just making a profit for shareholders. B Corporations are held publicly accountable to stakeholders beyond 
shareholders, such as employees, customers, the local community, and the environment. There are more than 2600 Certified B corporations across 60 countries (Feloni, 2018).

Increasing income inequality and the alarming rise in "deaths of despair" - a term coined by economists Anne Case and Angus Deaton in their 2020 book, Deaths of Despair and the Future of Capitalism - from suicide, overdoses, and alcoholism are only two of the symptoms of capitalism that is becoming dysfunctional.

In recent years, various ideas and proposals have emerged that aim to rewrite capitalism's social contract. What they have in common is the idea that businesses need more varied measures of success than simply profit and growth. In business, there's "conscious capitalism," inspired by the practices of so-called "ethical" brands. In policy, there's "inclusive capitalism", advocated by both the Bank of England and The Vatican, which advocates harnessing "capitalism for good". And in sustainability, there's the idea of "doughnut economics", a theory proposed by economist and author Kate Raworth, which suggests that it's possible to thrive economically as a society while also staying within social and planetary boundaries (King, 2021, para. 25).

Before firms can reach a level of being humanity-oriented, they have to create an ethical culture (Friedman \& Globerman, 2021). As noted above, organizations that treat ethics seriously must encourage transparency; B corporations commit to "satisfy the highest transparency." This paper shows that, as far back as 1800 years ago, the Talmud understood the importance of behaving in an aboveboard manner, one in which no one's suspicion is aroused that someone is doing something unethical. This includes having strict rules about conflicts of interest. In addition, one is obligated to judge another person favorably, but this is only true if the person does not have a reputation for being unethical. Finally, if there is a persistent rumor that an individual or an organization behaves unethically, there is an obligation to investigate.

\section{References}

Admati, A. R. (2019). How business schools can help restore trust in capitalism. Harvard Business Review, September. https://hbr.org/2019/09/how-business-schools-can-helprestore-trust-in-capitalism

Altman, A. (2017, June 8). The swamp hotel: How Trump's D.C. outpost became a dealmaker's paradise for diplomats, lobbyists and insiders. Time. https://time.com/magazine/us/4810463/june-19th-2017-vol-189-no-23-u-s/

Annan, K. (2016, February 3). The world has a leadership crisis, not a knowledge crisis. https://www.linkedin.com/pulse/world-has-leadership-crisis-knowledge-kofi-annan

Ardichvili, A., \& Jondle, D. (2009). Integrative literature review: Ethical business cultures: A literature review and implications for HRD. Human Resource Development Review, 8(2), 223-244. https://doi.org/10.1177/1534484309334098

Bazerman, M. H., \& Tenbrusel, A. E. (2011). Ethical breakdowns. Harvard Business Review, April, 58-65.

Bell, R.I., H.H. Friedman, H. H., \& Friedman, L. W. (2015). Conflict of interest: The common thread underlying ethical lapses. Electronic Journal of Business Ethics and Organization Studies, 10(1), 4-8. http://ejbo.jyu.fi/pdf/ejbo_vol10_no1_pages_48.pdf.

Carlisle, M. (2020, January 21).'A trust paradox.' new report finds distrust in capitalism, government and global institutions - despite a strong economy. Time. https://time.com/5768725/edelman-trust-barometer-2020/

Case, A., \& Deaton, A. (2020). Deaths of Despair and the Future of Capitalism. Princeton, 
NJ: Princeton University Press.

Cauterucci, C. (2017, April 21). What it takes. Slate.com. http://www.slate.com/articles/double_x/doublex/2017/04/o_reilly_s_out_trump_s_in_ what_does_it_take_to_topple_a_sexual_predator.html

Chêne, M. (2014). The impact of corruption on growth and inequality. Transparency International.

https://www.transparency.org/files/content/corruptionqas/Impact_of_corruption_on_g rowth_and_inequality_2014.pdf

Department of Justice (2020, November 24). Opioid manufacturer Purdue Pharma pleads guilty to fraud and kickback conspiracies. https://www.justice.gov/opa/pr/opioidmanufacturer-purdue-pharma-pleads-guilty-fraud-and-kickback-conspiracies

Egan, M. (2017, April 19). Feds knew of 700 Wells Fargo whistleblower cases in 2010. Money.cnn.com. http://money.cnn.com/2017/04/19/investing/wells-fargo-regulatorwhistleblower-2010-occ/

Feloni, R. (2018, December 8). More than 2,600 companies, like Danone and Patagonia, are on board with an entrepreneur who says the way we do business runs counter to human nature, and there's only one way forward. Business Insider. https://www.businessinsider.com/b-corporation-b-lab-movement-and1-cofounder2018-11

Fogel, J., \& Friedman, H. H. (2008). Conflict of interest and the Talmud. Journal of Business Ethics, 78, 237-46.

Friedman, H. H., \& Globerman, K. (2021). Ethics \& consciousness in organizations: A conceptual hierarchical model. Journal of Intercultural Management and Ethics, 3, 524. https://jime.csesm.org/index.php/JIME/article/view/191/154

Friedman, H. H., \& Kass, F. (2018, February 22). 'Substance over form': Meaningful ways to measure organizational performance. Available at SSRN: https://ssrn.com/abstract=3128595 or http://dx.doi.org/10.2139/ssrn.3128595

Greycourt (2008). The financial crisis and the collapse of ethical behavior. White Paper No. 44. https://icma.org/sites/default/files/301680_WhitePaper044-FinancialCrisis.pdf

Jewish Virtual Library (2017). Jonah ben Abraham Gerondi. Jewishvirtuallibrary.org. http://www.jewishvirtuallibrary.org/jonah-ben-abraham-gerondi-2

King, M. W. (2021, May 26). Why the next stage of capitalism is coming. BBC/Future. https://www.bbc.com/future/article/20210525-why-the-next-stage-of-capitalism-iscoming

Lipman, V. (2013, December 11). New study shows transparency isn't just good ethics-It's good business. Forbes. https://www.forbes.com/sites/victorlipman/2013/12/11/newstudy-shows-transparency-isnt-just-good-ethics-its-good-business

Mann, B. (2021, July 21). State attorneys general reach a \$26 Billion national opioid settlement. NPR. https://www.npr.org/2021/07/21/1018881195/state-attorneysgeneral-26-billion-opioid-settlement

Mayer, D. M., Kuenzi, M., Greenbaum, R., Bardes, M., \& Salvador, R. (2009). How low does ethical leadership flow? Test of a trickle-down model. Organizational Behavior and Human Decision Processes, 108, 1-13.

Monahan, K. (2012). A review of the literature concerning ethical leadership in organizations. Emerging Leadership Journeys, 5(1), 56-66.

Moore, M. (2021, July 22). WH's Jen Psaki grilled by reporters about the sale of Hunter Biden's artwork. New York Post. https://nypost.com/2021/07/22/psaki-grilled-byreporters-on-sale-of-hunter-bidens-artwork/

Oliveira, H. (2018, October 26). Interview of Raj Sisodia, co-founder of conscious capitalism. Uniapac World Congress. https://uniapaclisbon2018.com/interview-raj- 
sisodia-co-founder-of-conscious-capitalism/

Pearse, C. (2018, November 7). Five reasons why leadership is in crisis. Forbes. https://www.forbes.com/sites/chrispearse/2018/11/07/5-reasons-why-leadership-is-incrisis/\#701fdafb3aca

Shahid, S. (2014, November 7). Why the world in 2015 faces a leadership crisis? World Economic Forum. https://www.weforum.org/agenda/2014/11/world-2015-facesleadership-crisis/

Spithoff, S., Leece, P., Sullivan, F., Persaud, N., Belesiotis, P., \& Steiner, L. (2020). Drivers of the opioid crisis: An appraisal of financial conflicts of interest in clinical practice guideline panels at the peak of opioid prescribing. PloS one, 15(1), e0227045. https://doi.org/10.1371/journal.pone.0227045

Taubes, M. (2013, December 21). Suspecting the innocent. Shema Koleinu, Shemot, 18(12), 1-2. http://www.yutorah.org/sidebar/lecture.cfm/802098/shema-koleinu-editor/shemakoleinu-shemot/

Veldsman, T. (2016, August 29). Global leadership is in crisis - it's time to stop the rot. The Conversation. https://theconversation.com/global-leadership-is-in-crisis-its-time-tostop-the-rot-64495

World Economic Forum (2014). Top 10 trends of 2014: A lack of values in leadership. WEForum.org. http://reports.weforum.org/outlook-14/top-ten-trends-category-page/7a-lack-of-values-in-leadership/ 